\title{
Analisis Strategi Pemasaran dan Diferensiasi Produk Melalui Instagram Dalam Menciptakan Loyalitas Konsumen di Kedai Kopi Darling Habit
}

\author{
Nanda Annisa | Bambang Dwi Hartono | Muchdie Syarun
}

How to cite : Annisa, N.,\& Hartono, B., D.(2020). P Analisis Strategi Pemasaran dan Diferensiasi Produk Melalui Instagram Dalam Menciptakan Loyalitas Konsumen di Kedai Kopi Darling Habit. 1(1). Jurnal Jurnal Manajemen Bisnis dan Publik(JMBP). 20-32.

Opened Access Article

Published Online on 12 November 2020

期 Submit your paper to this journal 
Recieved: 09 Oktober 2020

Accepted: 2 November 2020

Published: 12 November 2020

${ }^{*}$ Corresponding author: Nanda Annisa, Universitas Muhammadiyah Prof Dr Hamka, Indonesia

E-mail:

nanda.ann@yahoo.com

Reviewing editor:

Sunarta,

Universitas

Muhammadiyah

HAMKA- Jakarta.

Additional information is available at the end of the article

\section{Analisis Strategi Pemasaran dan Diferensiasi Produk Melalui Instagram Dalam Menciptakan Loyalitas Konsumen di Kedai Kopi Darling Habit}

\author{
Nanda Annisa*1 ,Bambang Dwi Hartono2, Muchdie Syarun
}

Abstract. Abstrak. Tujuan dari penelitian ini adalah menganalisis penerapan strategi pemasaran konten melalui instagram dan strategi diferensiasi produk dalam rangka menciptakan loyalitas konsumen di Warung Kopi Darling Habit. Metode yang digunakan adalah deskriptif kualitatif. Pengumpulan data dilakukan dengan wawancara, observasi, dan dokumentasi. Penelitian ini juga didukung oleh data internal perusahaan. Hasil penelitian ini menunjukkan bahwa content marketing melalui Instagram membantu Darling Habit untuk mengenalkan brandnya kepada publik, meski dari segi visibilitas kedai tersebut jauh dari orang yang lalu lalang sehingga mudah terlihat. Strategi diferensiasi menimbulkan rasa loyalitas kepada pelanggannya. Hal ini juga didukung oleh strategi pemasaran lainnya yaitu pemasaran konten digital melalui aplikasi Instagram.

Key words: Strategi Pemasaran, Strategi Diferensiasi, Instagram.

\section{TENTANG PENULIS \\ Nanda Annisa adalah mahasiswa pascasarjana UHAMKA yang lulus pada tahun 2020. la saat ini sedang aktif dalam penelitian-penelitian yang terkait dengan pemasaran pada produk-produk lokal yang dipasarkan baik nasional ataupun international. .}

Bambang Dwi Hartono adalah Dosen Sekolah Pascasarjana Universitas Muhammadiyah Prof. DR. HAMKA pada program studi Magister Manajemen. la saat ini sedang aktif dalam berbagai penelitian terkait dengan manajemen dan bisnis pada kebijakan publik.

\section{Muchdie Syarun adalah Dosen Sekolah Pascasarjana Universitas Muhammadiyah Prof. DR. HAMKA pada program studi Magister Manajemen. la saat ini sedang aktif dalam berbagai penelitian terkait dengan manajemen dan bisnis pada kebijakan publik.}

\section{PENELITIAN SEBELUMNYA}

Penelitian sebelumnya membahas kajian manajemen terkait pemasaran produk-produk UMKM dengan diferensiasi produk agar menembus pasar global. Fokus pada kepemimpinan sumber daya manusia dalam meningkatan produktifitas. Saat ini peneliti membahas Analisis Strategi Pemasaran dan Diferensiasi Produk Melalui Instagram Dalam Menciptakan Loyalitas Konsumen di Kedai Kopi Darling Habit
. (c) 2020 The Author(s). This open access article is distributed under a Creative Commons Attribution (CC-BY) 4.0 license. 


\section{Pendahuluan}

'Darling Habit' merupakan sebuah kedai kopi yang juga menawarkan menu roti dan pastry yang berdiri pada tahun 2017 di kawasan Tebet, Jakarta Selatan. Meski kawasan Tebet dikenal sebagai tempat nongkrong anak muda karena didominasi oleh restoran dan kafe, kedai Darling Habit tidak berada di tengah kawasan, melainkan di lokasi yang berada di deretan kawasan pemukiman yang sepi, persis di seberang hutan kota yang indah. Tarigan (2005: 122) menjelaskan bahwa untuk menentukan lokasi suatu usaha perlu dilakukan pertimbangan yang matang karena lokasi usaha merupakan salah satu strategi dalam usaha yang dapat menentukan tingkat pendapatan suatu usaha.

Faktor pemilihan tempat atau lokasi usaha menurut Fandy (2009: 92) memerlukan pertimbangan yang matang antara lain sebagai berikut: 1) Akses, misalnya lokasi yang dilalui atau mudah dijangkau oleh sarana angkutan umum. 2) Visibility, yaitu suatu lokasi atau tempat yang dapat dilihat dengan jelas dari jarak pandang normal. 3) Lalu lintas menyangkut dua pertimbangan utama: a) Banyaknya orang yang lewat dapat memberikan peluang yang besar untuk terjadinya pembelian, yaitu keputusan pembelian yang sering terjadi secara spontan, tanpa perencanaan, dan atau tanpa melalui upaya khusus. b) Kemacetan lalu lintas juga bisa menjadi kendala. Tempat parkir yang luas, nyaman, dan aman baik untuk kendaraan roda dua maupun roda empat. 4) Pemekaran, yaitu tersedianya ruang yang cukup luas jika terjadi pemekaran di kemudian hari. Tarigan (2005: 145) kemudian juga menyimpulkan bahwa dalam teori pendekatan lokasi the losch, lokasi penjual sangat berpengaruh terhadap jumlah konsumen tempatnya bekerja. Semakin jauh dari tempat penjual, konsumen semakin enggan membeli karena biaya transportasi menuju tempat penjual semakin mahal. Produsen harus memilih lokasi yang menghasilkan penjualan terbesar yang identik dengan pendapatan terbesar. Pada kasus ini, Lokasi usaha merupakan salah satu faktor yang dapat mempengaruhi pendapatan karena lokasi usaha yang strategis dapat mempengaruhi tingkat pendapatan usaha. Penguatan Tarigan, Buchari (2012: 106) sampai pada kesimpulan bahwa salah satu hal yang akan menentukan tingkat keberhasilan dan kegagalan suatu usaha untuk masa depan adalah pemilihan lokasi usaha yang tepat dan strategis. Dalam pemilihan dan penentuan lokasi usaha ada dua langkah yang perlu ditentukan yaitu penentuan komunitas yang akan dilayani dan pemilihan lokasi di sekitar komunitas tersebut.

Uniknya, tidak semua kriteria lokasi bisnis tersebut di atas dipenuhi oleh Kedai Darling Habit, karena lokasinya tidak dapat diakses oleh kendaraan umum, meskipun dapat dengan mudah diakses dengan kendaraan pribadi, dari segi jarak pandang juga tidak terletak di jalan utama. akses jalan jadi kurang strategis untuk dilihat orang. Sepanjang dan sekitar, Darling Habit juga tidak memiliki area parkir khusus - hanya ada sedikit ruang di depan toko yang dapat digunakan untuk memarkir sepeda motor - tetapi untungnya, pelanggan dapat memarkir kendaraannya di tempat parkir hutan kota yang berada tepat di seberang toko. Namun berdasarkan observasi dan wawancara singkat dengan peneliti dengan karyawan Darling Habit, toko tersebut tidak pernah sepi pengunjung.

Peneliti juga mengamati review terkait toko ini pada website kuliner 'pergikuliner.com', dari 10 review, 4 menyatakan review positif dan ingin kembali lagi, 4 review positif, dan hanya 1 review negatif terkait tempat kecil dan ramai. pengunjung. Dari pengamatan kecil ini dapat disimpulkan bahwa toko "Darling Habit" telah berhasil menanamkan rasa loyalitas atau rasa loyalitas dari konsumen kepada toko tersebut. Loyalitas konsumen sendiri didefinisikan oleh Oliver (dalam Taylor, Celuch, dan Goodwin, 1999: 218) sebagai komitmen yang tinggi untuk membeli kembali suatu produk atau jasa yang disukai di masa depan, selain pengaruh situasi pemasar dan upaya untuk mengubah perilaku. . Dengan kata lain, konsumen akan loyal melakukan pembelian berulang secara terus menerus. Sedangkan menurut Wahyu Nugroho (2005). Merujuk pada uraian di atas mengenai store Darling Habit dan pencapaian yang telah diraihnya, maka dapat dipastikan strategi 
pemasaran yang baik dari tim Darling Habit tersebut. Strategi pemasaran pada dasarnya adalah suatu rencana yang komprehensif, terintegrasi dan terpadu dalam bidang pemasaran yang memberikan pedoman atas kegiatan-kegiatan yang akan dilakukan untuk mencapai tujuan pemasaran suatu perusahaan.

\section{Tinjauan Literatur}

Pemasaran Konten adalah pesan atau isi merupakan unsur komunikasi yang sangat penting termasuk dalam komunikasi pemasaran (Cangara, 2017). Dilansir dari Forbes (2019), pemasaran konten merupakan strategi pemasaran dalam membuat dan mendistribusikan konten yang bernilai, relevan, dan konsisten untuk menarik perhatian khalayak yang dituju. Menurut $\mathrm{J}$ Rowley (Yazdanifard dan Kee, 2015), pemasaran konten adalah manajemen yang memastikan identifikasi pasar yang pasti, dengan analisis yang kuat untuk menarik perhatian calon pelanggan yang didistribusikan melalui media digital. Menurut Content Marketing Institute (2017), pemasaran konten dapat didefinisikan sebagai strategi pemasaran yang berfokus pada pembuatan dan pendistribusian konten yang bernilai, relevan, dan konsisten untuk menarik dan mendapatkan audiens dengan tujuan akhir menghasilkan keuntungan bagi suatu bisnis. Content marketing dinilai mampu menciptakan kedekatan dengan khalayak sehingga pemasar dapat lebih mudah mencapai tujuan dari kegiatan komunikasi pemasaran. Namun syarat yang harus dipenuhi adalah relevansi konten dengan penonton (Gamble, 2016). Pemasaran konten dapat didistribusikan (dipublikasikan) melalui beberapa media, misalnya situs web, media sosial, blog, vlog, dan aplikasi di tablet dan smartphone. Pemilihan media ini disesuaikan dengan target pasar serta karakteristik isi dan tujuan pesan. Pemasaran konten dapat didistribusikan (dipublikasikan) melalui beberapa media, misalnya situs web, media sosial, blog, vlog, dan aplikasi di tablet dan smartphone. Pemilihan media ini disesuaikan dengan target pasar serta karakteristik isi dan tujuan pesan. Pemasaran konten dapat didistribusikan (dipublikasikan) melalui beberapa media, misalnya situs web, media sosial, blog, vlog, dan aplikasi di tablet dan smartphone. Pemilihan media ini disesuaikan dengan target pasar serta karakteristik isi dan tujuan pesan.

Diferensiasi Produk Menurut Sudaryono (2018: 214) "Diferensiasi produk adalah kegiatan memodifikasi suatu produk agar lebih menarik. Diferensiasi membutuhkan riset pasar yang cukup serius agar benar-benar berbeda, serta pengetahuan tentang produk pesaing. Menurut Dimyati (2018: 93) "Diferensiasi ini sangat penting dan cocok sebagai kunci sukses suatu perusahaan. Perusahaan dalam menjalankan usahanya harus menerapkan diferensiasi dimana diferensiasi merupakan salah satu jenis keunggulan bersaing yang dapat dimiliki suatu perusahaan. Yoga Pratama \& Seno Andri (2015: 4) berpendapat bahwa dalam diferensiasi produk, produk mempunyai makna atau nilai bahwa perusahaan menciptakan produk baru yang dirasakan oleh semua pelanggan sebagai produk yang unik dan berbeda.

Kotler (2019) menyarankan dimensi dalam diferensiasi produk, termasuk:

- Formulir (Form). Produk dapat dibedakan berdasarkan bentuk atau ukuran, model atau struktur fisik produk.

- Fitur (Feature). Produk yang ditawarkan memiliki fitur atau fitur yang berbeda dan melengkapi fungsi dasar produk tersebut. Upaya untuk menjadi yang pertama memperkenalkan fitur-fitur baru yang dianggap bernilai merupakan salah satu cara paling efektif untuk bersaing.

- Kualitas Kinerja. Kinerja produk dapat diartikan sebagai tingkat karakteristik produk dasar. Semakin tinggi kualitas produk, semakin tinggi tingkat karakteristiknya. Kinerja produk yang unggul menghasilkan lebih banyak pembelian berulang, loyalitas pelanggan, dan kesan pelanggan yang positif. 
- Conformance (Kualitas Kesesuaian). Pembeli mengharapkan produk tersebut memiliki kesesuaian dengan standar atau spesifikasi yang tinggi. Kesesuaian kualitas adalah tingkat kesesuaian dan pemenuhan seluruh unit yang diproduksi terhadap spesifikasi target yang dijanjikan.

- Daya Tahan Pembeli mengharapkan beberapa produk memiliki daya tahan dan / atau berat yang normal. Produk yang memiliki keunggulan durability akan menarik lebih banyak perhatian dari customer untuk membayar lebih untuk produk yang mereka harapkan.

- Reliability (Reliabilitas). Pembeli juga akan membayar lebih untuk produk yang memiliki keandalan. Reliabilitas adalah ukuran probabilitas bahwa produk tertentu tidak akan rusak atau gagal dalam jangka waktu tertentu.

- Mudah Diperbaiki (Repairability). Pembeli memilih produk yang mudah diperbaiki, yang merupakan ukuran kemudahan mereka untuk memperbaiki produk saat rusak atau rusak. Pelanggan tertarik pada jenis produk yang mudah diperbaiki karena alasan efisiensi waktu dan biaya jika dapat diperbaiki sendiri.

- Gaya (Style). Jelaskan penampilan dan perasaan yang diciptakan produk untuk pembeli. Gaya mempengaruhi konsumen dengan menampilkan keunikan dan performa pada produk untuk menarik minat beli konsumen.

- Desain (Design). Menjadi salah satu cara potensial paling kuat untuk membedakan dan memposisikan produk dan layanan perusahaan.

Loyalitas Konsumen Menurut Oliver (2014: 432) adalah komitmen yang dipegang teguh oleh konsumen untuk membeli atau mempromosikan suatu produk berupa barang atau jasa secara konsisten, hal ini menyebabkan terjadinya pembelian berulang pada merek yang sama, padahal konsumen tersebut mendapatkan pengaruh situasional atau pemasaran. dari pesaing untuk diubah ke merek lain. Jadi dapat disimpulkan bahwa loyalitas konsumen merupakan hasil yang diperoleh dari kepuasan konsumen terhadap suatu produk atau jasa, loyalitas ini berdampak positif pada perusahaan seperti konsumen setia yang melakukan pembelian berulang terhadap produk perusahaan. Menurut Mowen dan Minor, loyalitas konsumen adalah sikap positif terhadap merek, komitmen terhadap merek memiliki niat untuk melanjutkan pembelian di masa depan. Loyalitas konsumen ini disebabkan oleh pengaruh kepuasan atau ketidakpuasan terhadap merek yang terus menumpuk disamping persepsi kualitas produk (barang atau jasa) (Harnoto, 2014).

Loyalitas Konsumen Menurut Kotler dan Armstrong (2015: 49) menjaga loyalitas konsumen masuk akal secara ekonomi. Pelanggan setia menggunakan produk perusahaan lebih banyak dan untuk waktu yang lebih lama. Kehilangan pelanggan setia bisa berarti kehilangan aliran pendapatan dari pelanggan itu di masa depan. Ada tiga ciri pelanggan setia, antara lain: Kehilangan pelanggan setia bisa berarti kehilangan aliran pendapatan dari pelanggan itu di masa depan. Ada tiga ciri pelanggan setia, antara lain: Kehilangan pelanggan setia bisa berarti kehilangan aliran pendapatan dari pelanggan itu di masa depan. Ada tiga ciri pelanggan setia, antara lain:

- Ulangi Pembelian

Ini adalah kesediaan pelanggan untuk membeli atau menggunakan kembali produk atau layanan yang sama di masa depan.

- Referensi

Rujukan diartikan sebagai kesediaan pelanggan untuk memberikan rekomendasi produk atau layanan yang mereka gunakan kepada orang lain.

- Retensi 
Retensi merupakan suatu keadaan dimana Anda merasa terikat dengan suatu merek atau toko yang menyebabkan konsumen memilih produk atau toko tersebut padahal masih banyak alternatif lain.

Loyalitas pelanggan sangat dibutuhkan dalam keberlangsungan suatu perusahaan, dimana citra perusahaan yang baik, kepercayaan, reputasi merupakan faktor penting dalam terciptanya loyalitas pelanggan (Samsudin, 2018). Kerangka konseptual pada penelitian ini dapat dijelaskan sebagai berikut;

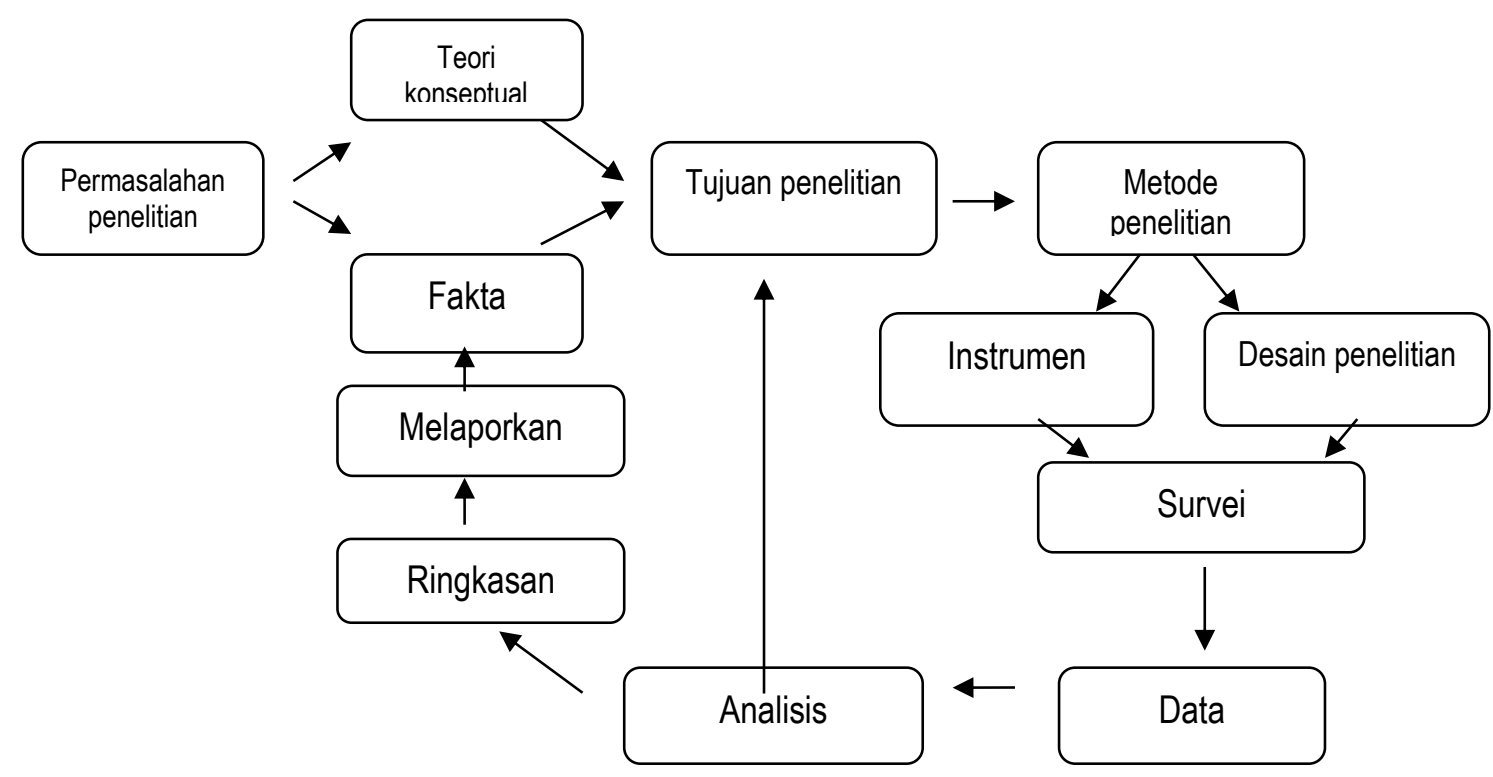

\section{Metode Penelitian}

Jenis metode penelitian yang digunakan dalam penelitian ini adalah metode penelitian kualitatif deskriptif. Menurut Moeleong, metode penelitian kualitatif merupakan penelitian ilmiah yang bertujuan untuk memahami suatu fenomena dalam konteks sosial yang natural dengan mengedepankan proses interaksi komunikasi yang mendalam antara peneliti dengan fenomena yang diteliti (Sugiyono, 2015). Dalam mengumpulkan, mengungkapkan berbagai masalah dan tujuan yang ingin dicapai, penelitian ini dilakukan dengan menggunakan pendekatan studi deskriptif analitik.

Sebelum penulis menentukan objek penelitian, penulis terlebih dahulu mengamati fenomena yang terjadi pada objek penelitian yaitu kedai kopi Darling Habit. Setelah tertarik dengan fenomena yang terjadi di warung tersebut maka penulis menetapkan kedai kopi Darling Habit sebagai objek penelitian. Kemudian penulis melakukan penelitian secara mendalam terhadap permasalahan yang terjadi di kedai kopi Darling Habit. Penelitian mendalam ini dilakukan oleh penulis dengan melakukan wawancara dengan pemilik toko, pengelola, dan staf pemasaran kedai Darling Habit sehingga didapatkan hasil bahwa penulis mendapatkan fakta awal dari kedai kopi Darling Habit yang kemudian dicocokkan. penulis dengan teori dan konsep penelitian.

Langkah selanjutnya, penulis merancang desain penelitian dan menentukan instrumen yang digunakan untuk memperoleh data. Dalam hal pengumpulan data, selain melakukan wawancara, memperoleh data internal berupa grafik penjualan tahunan guna mengukur keberhasilan implementasi strategi pemasaran toko, penulis juga melakukan observasi di toko yang didokumentasikan dan dicatat serta diolah menjadi data. 
Menurut Neuman (1997) analisis kualitatif merupakan klasifikasi fenomena sosial (variabel nominal \& ordinal tanpa pengukuran korelasi statistik), dan hanya melibatkan beberapa partisipan sebagai informan. Maka setelah mendapatkan data internal dari 3 informan dari dalam instansi yang akan diwawancarai, selanjutnya penulis juga melakukan survey untuk mendapatkan data eksternal dari 10 informan pelanggan, dan kurang lebih 20 informan pengguna media sosial. Hasilnya penulis mendapatkan data yang kemudian penulis analisis untuk menghasilkan suatu kesimpulan.

Instrumen Penelitian yang digunakan dalam penelitian ini adalah pertama, pengamatan dengan cara melakukan observasi yang disertai dengan catatan tentang keadaan atau tingkah laku objek sasaran. Metode observasi yang dilakukan adalah melakukan observasi langsung ke objek penelitian untuk melihat dari dekat aktivitas pemasaran yang dilakukan oleh toko Darling Habit, beserta perilaku konsumen toko tersebut. Kedua, wawancara yang merupakan suatu bentuk komunikasi antara dua orang yang melibatkan seseorang yang ingin mendapatkan informasi dari orang lain dengan mengajukan pertanyaan berdasarkan tujuan tertentu. Wawancara dilakukan langsung oleh peneliti di lokasi penelitian dengan menggunakan informasi dari pemilik, pekerja dan pelanggan toko Darling Habit. Ketiga, dokumentasi dilakukan untuk memperoleh data tentang berbagai jenis kegiatan usaha pemasaran yang didokumentasikan baik dalam berbagai catatan kegiatan maupun dalam metode pemasaran. Terakhir, survey dilakukan dengan cara menyebarkan kuesioner kepada 10 pelanggan sebagai informan mengenai penerapan strategi diferensiasi produk untuk toko Darling Habit, dan kurang lebih 20 pengguna Instagram sebagai informan mengenai implementasi strategi pemasaran konten melalui Instagram. Data ini akan disajikan sebagai persentase.

Teknik Analisis Data dengan dua cara yaitu pertama, data Internal artinya, data yang menggambarkan keadaan atau aktivitas suatu lembaga yang dikumpulkan sendiri dan hasil datanya digunakan oleh lembaga itu sendiri. Dalam hal ini, penulis akan menggunakan data internal penjualan toko Darling Habit untuk merepresentasikan berhasil tidaknya toko tersebut dalam menerapkan strategi pemasaran. Kedua, data eksternal yaitu data yang menggambarkan kondisi atau kegiatan di luar instansi dan data yang tidak terdapat pada kegiatan internal suatu instansi. Dalam penelitian ini penulis akan menggunakan dua metode pengukuran data model Customer Windows.

Jendela pelanggan adalah ukuran pemahaman ekspektasi pelanggan, yang diakui oleh Arbor Inc., firma riset pasar dan Total Quality Management di Philadelphia. Ukuran ini mengukur kepuasan dan harapan pelanggan, yang digambarkan dalam grafik Cartesian. Dalam penelitian ini, pengukuran metode customer windows dapat dilakukan untuk mengetahui apa yang menjadi prioritas pelanggan terhadap suatu produk toko, sehingga toko Darling Habit dapat menggunakan hasil tersebut sebagai pedoman dalam memberikan strategi pemasaran. Melalui pengukuran ini, solusi dari rumusan masalah juga dapat diidentifikasi. Berikut adalah matriks pengukuran jendela pelanggan yang akan penulis gunakan untuk penelitian ini: 


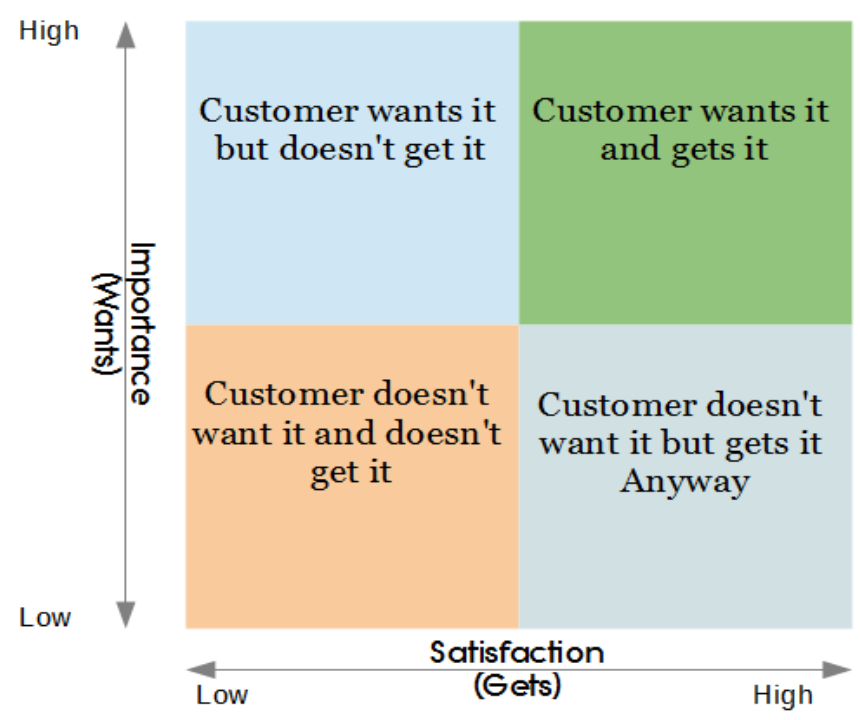

\section{Pembahasan}

Sebelum dua strategi pemasaran utama yaitu strategi pemasaran konten melalui Instagram dan strategi diferensiasi produk, terlebih dahulu penulis ingin menjelaskan terlebih dahulu strategi pemasaran yang digunakan oleh toko Darling Habit yaitu strategi komunitisasi. Sebagaimana dijelaskan dalam tinjauan teoritis, dalam konsep pemasaran lama yang disebut juga era vertikal telah dikenal 9 elemen yang berkaitan dengan pemasaran, seperti segmentasi, penargetan, positioning, diferensiasi, bauran pemasaran, penjualan, merek, layanan, dan proses. Sembilan hal pada era horizontal yaitu era new wave marketing telah bergeser misalnya dari segmentasi ke komunikasi, target ke konfirmasi, positioning ke klarifikasi, diferensiasi ke kodifikasi.

Dalam teori new wave marketing, komunikasi merupakan pembaharuan dari strategi pemasaran yang lama yaitu segmentasi. Segmentasi adalah seni mengidentifikasi dan memanfaatkan peluang di pasar dengan melihat pasar secara kreatif. Segmentasi mengklasifikasikan pasar berdasarkan atribut yang statis atau dinamis. Contoh dari jenis atribut statis adalah segmentasi berdasarkan variabel geografis dan demografis. Sedangkan segmentasi berdasarkan atribut dinamis didasarkan pada nilai psikografis, perilaku atau perilaku. Di era New Wave, praktik segmentasi kini mengkomunikasikan konsumen sebagai sekelompok orang yang peduli satu sama lain dan memiliki tujuan, nilai, dan identitas yang sama. Komunitisasi sebagai strategi, bukan sebagai taktik, jadi komunitisasi adalah langkah awal dalam strategi. Dengan demikian, semua keputusan pemasaran strategis pada akhirnya harus sejalan dengan kesejahteraan masyarakat. Jika komunikasi ini tidak ditempatkan pada level strategis alias hanya untuk pemasaran taktis, maka langkah membangun komunitas bisa jadi gagal. Komunikasi dapat dilakukan dengan beberapa cara:

- Kita bisa mendengarkan (mendengarkan) apapun yang dibicarakan dalam suatu komunitas.

- Kita bisa berbicara (berbicara) dengan komunitas dan memberdayakannya (memberi energi).

- Kami dapat membantu.

- Kita bisa merangkul masyarakat terkait. 


\subsection{Strategi Pemasaran Konten Melalui Instagram}

Kedai Darling Habit menggunakan platform digital yaitu aplikasi Instagram untuk melakukan pemasaran konten dengan nama akun @darlinghabitsignature. Melalui platform media digital Instagram, Darling Habit memperkenalkan brand tokonya kepada publik. Mereka memposting gambar menu makanan dan minuman yang dijual di toko mereka. Foto-fotonya diambil serapi mungkin sehingga menarik untuk dipandang. Dalam sehari, setidaknya akun Darling Habit memposting 1 hingga 3 foto setiap hari. Tidak lupa akun ini juga memperbaiki testimoni pelanggan pada fitur Instagram story yang berdurasi kurang lebih 15 detik.

Selain memposting foto di akun Instagram miliknya, Darling Habit juga mengandalkan foto yang dibagikan oleh akun Instagram pelanggan yang pernah datang ke toko tersebut. Staf pemasaran konten Darling Habit tidak langsung meminta pengunjung toko untuk berfoto kemudian di-posting di Instagram dengan memasukkan akun Instagram toko Darling Habit, namun mengetahui ciri-ciri perilaku kaum milenial yang suka berfoto di tempat-tempat yang bagus dan unik. lalu membagikannya di media sosial masing-masing, bagian pemasaran toko Darling Habit memiliki strategi mendekorasi toko serapi, senyaman, dan seunik mungkin agar pelanggan tertarik untuk berfoto. Hingga saat ini, kedai kopi Darling Habit memiliki lebih dari 400 feed-tag, lebih dari 300 geotag,

\subsection{Strategi Diferensiasi Produk}

Menurut Kotler dalam Tri Agus dkk (2019) dimensi diferensiasi produk meliputi:

- Formulir (Form). Produk dapat dibedakan berdasarkan bentuk atau ukuran, model atau struktur fisik produk.

- Fitur (Feature). Produk yang ditawarkan memiliki fitur atau keistimewaan yang berbeda dan melengkapi fungsi dasar produk. Upaya untuk menjadi yang pertama memperkenalkan fitur-fitur baru yang dianggap bernilai merupakan salah satu cara paling efektif untuk bersaing.

- Kualitas Kinerja. Kinerja produk dapat diartikan sebagai tingkat karakteristik produk dasar. Semakin tinggi kualitas produk, semakin tinggi tingkat karakteristiknya. Kinerja produk yang unggul menghasilkan lebih banyak pembelian berulang, loyalitas pelanggan, dan kesan pelanggan yang positif.

- Conformance (Kualitas Kesesuaian). Pembeli mengharapkan produk tersebut memiliki kesesuaian dengan standar atau spesifikasi yang tinggi. Kesesuaian kualitas adalah tingkat kesesuaian dan pemenuhan seluruh unit yang diproduksi terhadap spesifikasi target yang dijanjikan.

- Daya Tahan Pembeli mengharapkan beberapa produk memiliki daya tahan dan / atau berat yang normal. Produk yang memiliki keunggulan durability akan menarik lebih banyak perhatian dari customer untuk membayar lebih untuk produk yang mereka harapkan.

- Reliabilitas (Realibility). Pembeli juga akan membayar lebih untuk produk yang memiliki keandalan. Reliabilitas adalah ukuran probabilitas bahwa produk tertentu tidak akan rusak atau gagal dalam jangka waktu tertentu.

- Mudah Diperbaiki (Repairability). Pembeli memilih produk yang mudah diperbaiki, yang merupakan ukuran kemudahan mereka untuk memperbaiki produk saat rusak atau rusak. Pelanggan tertarik pada jenis produk yang mudah diperbaiki karena alasan efisiensi waktu dan biaya jika dapat diperbaiki sendiri.

- Gaya (Style). Jelaskan penampilan dan perasaan yang diciptakan produk untuk pembeli. Gaya mempengaruhi konsumen dengan menampilkan keunikan dan performa pada produk untuk menarik minat beli konsumen. 
- Desain (Design). Menjadi salah satu cara potensial paling kuat untuk membedakan dan memposisikan produk dan layanan perusahaan.

Sesuai dengan uraian Kotler di atas, poin 8 dan 9 merupakan referensi yang diimplementasikan oleh toko Darling Habit sebagai strategi diferensiasi produk, dalam hal ini produk yang dimaksud adalah toko tersebut.

Di kawasan Tebet Jakarta Selatan sendiri sangat didominasi oleh resto dan warung modern yang mengusung konsep bangunan perkotaan minimalis. Lokasinya pun kerap berdekatan, seperti di kawasan Tebet Raya yang memiliki lebih dari lima kedai kopi dalam satu lokasi. Namun seperti yang telah dijelaskan pada chapter sebelumnya, toko Darling Habit tidak berada di lokasi yang strategis ini melainkan berada di Jl. Tebet Barat Dalam yang berada di deretan perumahan sedikit berseberangan dengan hutan kota. Ini karena toko Darling Habit mengandalkan aset yang tersedia, atau aset yang tersedia tanpa harus membeli atau mengeluarkan modal baru untuk bisnis tersebut. Aset yang tersedia adalah rumah-rumah yang kemudian diubah menjadi kedai kopi. Mengandalkan aset yang ada menjadikan lokasi Darling Habit jauh dari strategis sebagai patokan untuk membangun bisnis toko. Maka untuk menyiasati toko agar bisa terjangkau oleh masyarakat, Darling Habit mengusung strategi diferensiasi produk dengan memanfaatkan suasana yang disajikan di area toko tersebut. Berawal dari testimoni pengunjung yang notabene merupakan komunitas yang diundang oleh pemilik toko Darling Habit.

Berdasarkan testimoni masyarakat yang diajak oleh pak Arief ke tokonya yang mengatakan bahwa toko pak Arief kecil tapi nyaman dan teduh karena berada di seberang hutan kota, pak Arief hati-hati menjadikan ini salah satu referensi yang kemudian menjadi strategi pemasaran andalannya; yaitu dengan membedakan konsep toko ini berbeda dengan konsep lainnya. Ketika toko-toko lain ramai dan terkesan modern, Pak Arief secara total mendesain toko tersebut menjadi toko dengan suasana teduh yang dipenuhi dengan tanaman hias hijau dan properti kuno lusuh yang terbuat dari kayu. Berbicara tentang produk, saat ini lagu tidak hanya berfokus pada makanan dan minuman yang ditawarkan, tetapi layanan kenyamanan yang diberikan oleh toko-toko Darling Habit, yang kemudian menjadi layanan yang paling sukses dan berperan dalam menciptakan loyalitas konsumen.

Hasil kuisioner yang disebarkan ke pengguna Instagram, 93\% konsumen menyatakan bahwa yang menarik mereka ke toko Darling Habit adalah tempatnya. Sedangkan hasil kuisioner yang disebarkan kepada 10 pelanggan toko Darling Habit yang mengunjungi toko tersebut, sebanyak 50\% menyatakan ingin kembali karena tempatnya nyaman, 30\% menyatakan lebih tertarik memesan melalui ojek online, sedangkan $20 \%$ mengaku bahwa mereka tidak memiliki kesan tertentu pada toko tersebut.

Menurut Griffin (2019), loyalitas menggambarkan suatu kondisi yang terjadi pada suatu waktu dan mensyaratkan bahwa aktivitas pembelian tidak hanya terjadi satu kali atau hanya dua kali, tetapi pembelian berulang lebih dari dua kali. Secara sederhana, loyalitas dapat diartikan sebagai perilaku pembelian. Pelanggan setia tercermin dalam perilaku berikut:

- Lakukan pembelian berulang secara teratur.

- Membeli produk dan layanan interline

- Merujuk pada orang lain

- Menunjukkan kekebalan untuk menarik dari pesaing

$50 \%$ pengunjung Darling Habit mengatakan ingin kembali ke toko dengan pertimbangan makanannya cukup enak dan tempatnya nyaman. Persentase tersebut merupakan persentase terbesar jika dibandingkan dengan 2 poin lainnya yaitu $20 \%$ menyatakan tidak ada kesan apapun, 
dan 30\% menyatakan lebih bersedia memesan melalui ojek online. Merujuk pada definisi Griffin tentang customer loyalty yaitu adanya pembelian berulang (kunjungan), maka Darling Habit bisa dikatakan cukup berhasil dalam menciptakan loyalitas konsumen. Masih menurut Griffin, ciri-ciri loyalitas konsumen dapat dilihat ketika pengunjung merekomendasikan produk tersebut kepada orang lain, dalam hal pemasaran teori Customer Path disebut juga advokat, di mana pemasaran target tidak lagi menggunakan produk ini untuk diri mereka sendiri tetapi telah merekomendasikannya kepada orang lain. Secara umum, 70\% pengunjung Darling Habit mengetahui tentang toko dari teman mereka. Seperti yang diungkapkan Griffin, salah satu ciri kuat dari customer loyalty adalah ketika customer merekomendasikan produk kepada orang lain alias melakukan advokasi. Jadi, sebanyak $70 \%$ pelanggan Darling Habit secara umum telah menumbuhkan loyalitas terhadap toko Darling Habit.

\section{Kesimpulan}

Berdasarkan hasil penelitian kualitatif dengan menggunakan teknik observasi, wawancara, dan dokumentasi yang dilakukan di toko Darling Habit dengan fokus pada menganalisis strategi pemasaran dalam menciptakan loyalitas konsumen dapat diambil kesimpulan bahwa content marketing melalui Instagram membantu Darling Habit untuk mengenalkan brandnya kepada publik, meskipun dari segi visibilitas toko tersebut jauh dari orang yang lalu lalang sehingga mudah terlihat. Sayangnya, toko Darling Habit masih belum mendalami teknik pemasaran konten melalui Instagram. Jika strategi ini diterapkan secara maksimal maka branding image toko ini akan semakin luas dan bisnis toko akan menjangkau target pasar yang maksimal.

Berdasarkan analisis yang didukung oleh data, dapat disimpulkan bahwa toko Darling Habit meskipun memiliki kekurangan dari segi lokasi - cukup berhasil menjadikan kekurangan tersebut sebagai strategi pemasaran untuk menarik minat konsumen dengan memberikan toko tersebut. konsep yang berbeda dari kebanyakan kedai kopi. . Strategi ini juga dikenal sebagai strategi diferensiasi. Perbedaan toko Darling Habit yang jauh dari keramaian dan hiruk pikuk meski berada di tengah kota menimbulkan rasa loyalitas kepada pelanggannya karena toko dengan konsep ini sangat jarang ditemukan di Jakarta. Strategi diferensiasi ini juga didukung oleh strategi pemasaran lainnya yaitu pemasaran konten digital melalui aplikasi Instagram. Strategi ini turut memperkenalkan keunikan toko Darling Habit kepada public..

Beberapa faktor yang menyebabkan beberapa kelemahan dalam strategi pemasaran yang telah dilakukan oleh toko Darling Habit yaitu kurangnya luas lahan khususnya untuk tempat parkir. Sementara karena lokasinya yang tidak strategis, sebagian besar pelanggan Darling Habit membawa kendaraan sendiri. Selain itu, kelemahan lain dari strategi pemasaran toko Darling Habit adalah kurangnya eksplorasi penggunaan fasilitas promosi pada aplikasi Instagram karena jumlah followers yang kurang memadai.

\section{Referensi}

Anitha J., (2014) "Penentu keterlibatan karyawan dan dampaknya terhadap kinerja karyawan", Jurnal Internasional Produktivitas dan Manajemen Kinerja.63(3),h.308-323.

Galup, (2013). Kondisi tempat kerja global: Wawasan keterlibatan karyawan untuk para pemimpin bisnis. Gallup. Diakses tanggal 14 Oktober 2019, dari

Glassdoor, (2016), Glassdoor Survey Menunjukkan Lebih Dari 1 Dari 3 Karyawan Akan Mencari A 
Harris, A. et al., (2007). Kepemimpinan terdistribusi dan perubahan organisasi: Meninjau bukti. Jurnal Perubahan Pendidikan, 8 (4), hlm.337-347.

Kahn, WA (1990) 'Kondisi psikologis dari keterlibatan pribadi dan pelepasan di tempat kerja', Academy of Management Journal, Vol 33, pp692-724.

Maha Ahmed Zaki Dajani, (2018) "The Impact of Employee Engagement on Job Performance dan Organizational Commitment in the Egyptian Banking Sector." Jurnal IImu Bisnis dan Manajemen. 3(1).h.138-147.

Maingi, AM, Rotich. G. \& Anyango, W. (2018). Pengaruh Gaya Kepemimpinan Terhadap Kinerja Organisasi Di Grup Radio Afrika. Jurnal Strategis Bisnis \& Manajemen Perubahan. 5(1).h.894 - 915.

Mani, V. (2011). Analisis Keterlibatan Karyawan dan prediktornya. Jurnal Internasional Studi Sumber Daya Manusia.1(2).

Marshall dan Molly. 2011. Prinsip-Prinsip Kepemimpinan. Erlangga. Jakarta.

Mathis, RL dan Jackson, JH (2011), Manajemen Sumber Daya Manusia, Pembelajaran Cengage SouthWestern, Mason, $\mathrm{OH}$.

Mathis, RL dan Jackson, JH (2011), Manajemen Sumber Daya Manusia, Pembelajaran Cengage SouthWestern, Mason, $\mathrm{OH}$.

Mayo, A (2016). Sumber Daya Manusia atau Sumber Daya Manusia ?: Mengelola Orang sebagai Aset, New York, Routledge.

Mboga, J dan Troiani, K. (2018), Studi Empiris: Keterlibatan Karyawan dan Kaitan dengan Kinerja dan Keberlanjutan Organisasi, Jurnal Internasional Bisnis \& IImu Terapan.7(2).h 42-56.

Mitonga-Monga, J. \& Coetzee, M., 2012. Gaya kepemimpinan yang dirasakan dan partisipasi karyawan. Jurnal Afrika Manajemen Bisnis, 6 (15).

Robbins, Stephen P dan Coulter, Mary K (2018). Pengelolaan. New York, NY: Pearson Education, [2018]. $15 E$ [edisi]

Robertson-Smith Dan Markwick (2009), Employee Engagement: A Review Of Current Thinking, Institute For Employment Studies, Mantell Building, University Of Sussex Campus Brighton

Schaufeli, WB, \& Bakker, AB (2004). Tuntutan pekerjaan, sumber daya pekerjaan, dan hubungannya dengan kelelahan dan keterlibatan: Multi-studi sampel. Jurnal Perilaku organisasi, 25 (3), 293315.

Shaskin, Marshall \& Molly. (2011). Prinsip-Prinsip Kepemimpinan. Jakarta: Erlangga.

Shuck, B., \& Herd, AM (2012). Keterlibatan dan Kepemimpinan Karyawan. Tinjauan Pengembangan Sumber Daya Manusia, 11 (2), 156-181. doi: 10.1177 / 1534484312438211

Soekarso, Agus Sosro, Iskandar Putong, Cecep Hidayat. (2010). Teori Kepemimpinan, Mitra Wacana Media, Jakarta

Syofian Siregar, IR.MM,. (2017). Metode Penelitian Kuantitatif. Jakarta, Kencana 
Srikanth, CP. dan Saraswathi, AB (2018), Employee Engagement As A Driver For The Organizational Performance, International Journal Of Core Engineering \& Management. 5(2).

Sugiyono.(2017). Metode Penelitian Kuantitatif Kualitatif dan R \$ D, Bandung, Alfabeta,

Turner, JR, \& Müller, R. (2005). Gaya Kepemimpinan Manajer Proyek sebagai Faktor Sukses pada Proyek: Tinjauan Pustaka. Jurnal Manajemen Proyek, 36 (2), 49-61. doi: 10.1177 / 875697280503600206

Vidya dan Lukas.(2018), Studi Dampak Employee Engagement terhadap Kinerja Karyawan, International Journal of Engineering Science and Computing.9(3).

Yeung dan Berman, (1997), Menambahkan Nilai Melalui Sumber Daya Manusia: Reorientasi Pengukuran Sumber Daya Manusia Untuk Mendorong Kinerja Bisnis, Manajemen Sumber Daya Manusia, Musim Gugur 1997, Vol. 36, No. 3, Hal. 321-335

Zainal, Veithzal Rivai, dkk. (2014). Manajemen Sumber Daya Manusia Untuk Perusahaan Dari Teori Ke Praktik. Depok. PT Rajagrafindo Persada.

Zhang, T. (2011). Hubungan antara gaya kepemimpinan yang dirasakan dan manajemen karyawan: Peran moderat dari karakteristik karyawan. Diakses pada 18 Oktober 2019 dari http://hdl.handle.net/1959.14/133300 di 18.10.19 